\title{
Comparing soil carbon loss through respiration and leaching under extreme precipitation events in arid and semiarid grasslands
}

\author{
Ting Liu ${ }^{1, *}$, Liang Wang ${ }^{1, *}$, Xiaojuan Feng ${ }^{1,2}$, Jinbo Zhang ${ }^{3}$, Tian Ma ${ }^{1,2}$, Xin Wang ${ }^{1,2}$, and Zongguang Liu ${ }^{1}$ \\ ${ }^{1}$ State Key Laboratory of Vegetation and Environmental Change, Institute of Botany, Chinese Academy of Sciences, \\ Beijing 100093, China \\ ${ }^{2}$ University of Chinese Academy of Sciences, Beijing, China \\ ${ }^{3}$ School of Geography Sciences, Nanjing Normal University, Nanjing 210023, China \\ *These authors contributed equally to this work.
}

Correspondence: Xiaojuan Feng (xfeng@ibcas.ac.cn)

Received: 23 June 2017 - Discussion started: 18 July 2017

Revised: 2 February 2018 - Accepted: 22 February 2018 - Published: 16 March 2018

\begin{abstract}
Respiration and leaching are two main processes responsible for soil carbon loss. While the former has received considerable research attention, studies examining leaching processes are limited, especially in semiarid grasslands due to low precipitation. Climate change may increase the extreme precipitation event (EPE) frequency in arid and semiarid regions, potentially enhancing soil carbon loss through leaching and respiration. Here we incubated soil columns of three typical grassland soils from Inner Mongolia and the Qinghai-Tibetan Plateau and examined the effect of simulated EPEs on soil carbon loss through respiration and leaching. EPEs induced a transient increase in $\mathrm{CO}_{2}$ release through soil respiration, equivalent to 32 and $72 \%$ of the net ecosystem productivity (NEP) in the temperate grasslands (Xilinhot and Keqi) and $7 \%$ of NEP in the alpine grasslands (Gangcha). By comparison, leaching loss of soil carbon accounted for 290, 120, and $15 \%$ of NEP at the corresponding sites, respectively, with dissolved inorganic carbon (DIC, biogenic DIC + lithogenic DIC) as the main form of carbon loss in the alkaline soils. Moreover, DIC loss increased with recurring EPEs in the soil with the highest $\mathrm{pH}$ due to an elevated contribution of dissolved $\mathrm{CO}_{2}$ from organic carbon degradation (indicated by DIC- $\delta{ }^{13} \mathrm{C}$ ). These results highlight the fact that leaching loss of soil carbon (particularly in the form of DIC) is important in the regional carbon budget of arid and semiarid grasslands and also imply that SOC mineralization in alkaline soils might be underestimated if only measured as $\mathrm{CO}_{2}$ emission from soils into the atmosphere. With a projected increase in EPEs under climate change, soil
\end{abstract}

carbon leaching processes and the influencing factors warrant a better understanding and should be incorporated into soil carbon models when estimating carbon balance in grassland ecosystems.

\section{Introduction}

Soils store approximately $2500 \mathrm{Pg}$ of carbon (including organic and inorganic carbon) globally, equivalent to 3.3 and 4.5 times the carbon in the atmosphere $(760 \mathrm{Pg})$ and terrestrial plants $(560 \mathrm{Pg})$, respectively (Lal, 2004). Slight variations in the soil carbon pool will hence severely influence atmospheric $\mathrm{CO}_{2}$ concentrations and have important implications for climate change (Davidson and Janssens, 2006; Trumbore and Czimczik, 2008). Respiration and leaching are two main processes responsible for soil carbon loss. While respiration has received considerable research attention (Raich and Schlesinger, 1992; Raich and Potter, 1995; Hoover et al., 2016; Burri et al., 2015; Escolar et al., 2015), leaching is relatively poorly constrained despite its importance in certain ecosystems (Cole et al., 2007; Battin et al., 2008; Liu et al., 2017). For instance, soil carbon leached from forests, grasslands, and croplands is estimated to be 15.1, 32.4 , and $20.5 \mathrm{~g} \mathrm{C} \mathrm{m}^{-2} \mathrm{yr}^{-1}$ across Europe, representing 4, 14 , and $8 \%$ of net ecosystem exchange (NEE), respectively (Kindler et al., 2011). Additionally, leaching of carbon previously preserved in surface litter and soil layers is believed to be a main source of dissolved organic and inorganic matter 
in inland waters (Spencer et al., 2008). In particular, soil inorganic carbon (SIC) that occurs widely in arid and semiarid regions is more prone to leaching than organic carbon during sporadic high precipitation events (Lal and Kimble, 2000). Despite the importance of leaching loss in regional soil carbon budgets, very little detailed data exists to investigate and compare the relative contribution of respiration and leaching processes to soil carbon loss.

Climate change is reported to increase the frequency as well as the intensity of extreme precipitation events (EPEs; Knapp et al., 2002; Goswami et al., 2006; Parry et al., 2007; Min et al., 2011; Reichstein et al., 2013), especially in arid regions (Donat et al., 2017). In northwestern China, the frequency and intensity of EPEs have shown an increasing trend in the most recent 50 years, constituting a much higher proportion of total precipitation than light precipitation events (Liu et al., 2005; Chen et al., 2012; Wang et al., 2012, 2014; Fu et al., 2013). Increasing EPEs will not only enhance soil carbon leaching but also affect soil respiration processes by increasing soluble substrates for microbial decomposition and potentially inducing hypoxic conditions (Knapp et al., 2002; Harper et al., 2005; Morel et al., 2009; Unger et al., 2010). Hence, it is critical to evaluate the effects of EPEs on soil respiration and leaching processes in order to better understand the impact of climate change on terrestrial carbon cycling, especially in arid and semiarid regions.

Grasslands, containing $20 \%$ of the global soil carbon pool, are the most widespread ecosystems in arid and semiarid regions globally (Jobbagy and Jackson, 2000). The deposition rate of carbonate is relatively high in grassland soils with a high alkalinity and aridity (Lal, 2008; Yang et al., 2012), and hence SIC is the major form of soil carbon in many grasslands (Mi et al., 2008). SIC storage in China is approximately 53.3-77.9 Pg (Li et al., 2007; Mi et al., 2008), $54 \%$ of which is mainly distributed in the temperate and alpine grasslands located in Inner Mongolia and the Qinghai-Tibetan Plateau (Mi et al., 2008). From the 1980s to 2000s, SIC in the topsoil of Chinese grasslands was estimated to decrease by $26.8 \mathrm{~g} \mathrm{C} \mathrm{m}^{-2} \mathrm{yr}^{-1}$, mainly attributed to soil acidification (Yang et al., 2012). Alternatively, precipitation is one of the main factors influencing the distribution and storage of SIC in arid and semiarid regions (Batjes, 1998; Lal and Kimble, 2000). Mi et al. (2008) found that $84 \%$ of SIC in China was distributed in areas with a mean annual precipitation (MAP) of $<500 \mathrm{~mm}$ and that SIC content decreased significantly with the increase in MAP. Given the high leaching potential of SIC in grassland soils under altered precipitation patterns in the future, we hypothesize that EPEs may significantly enhance SIC loss through leaching processes and further reduce SIC storage in grasslands.

In this study, soils were collected from varied depths of three typical temperate and alpine grasslands in Inner Mongolia and the Qinghai-Tibetan Plateau to construct soil columns for a laboratory incubation study. Using simulated EPEs, we examined soil carbon loss through respiration and leaching processes and compared their fluxes after EPEs. In addition, the leaf litter of a $\mathrm{C}_{4}$ grass was added to the surface of one set of soil columns to compare soil carbon loss from bare versus litter-covered soils and to estimate the contribution of litter-derived carbon to soil respiration after EPEs. Our research objectives were (1) to investigate the influence of EPEs on soil respiration, (2) to quantify the loss of SIC and soil organic carbon (SOC) through leaching during EPEs, and (3) to compare the relative importance of respiration and leaching in EPE-induced soil carbon loss from grassland soils.

\section{Materials and methods}

\subsection{Study area}

For the incubation experiment, soils were collected from three different sites of temperate and alpine grasslands in China with varied environmental characteristics. Temperate grasslands were sampled near Xilinhot (XLHT; $116^{\circ} 22^{\prime} \mathrm{E}$, $44^{\circ} 8^{\prime} \mathrm{N}$; mean elevation $1170 \mathrm{~m}$ ) and Keqi (KQ; $117^{\circ} 15^{\prime} \mathrm{E}$, $43^{\circ} 18^{\prime} \mathrm{N}$; mean elevation $1250 \mathrm{~m}$ ) within the arid and semiarid regions of Inner Mongolia (Fig. S1 in the Supplement) with MAP of 299 and $402 \mathrm{~mm}$ and mean annual temperature (MAT) of 1.2 and $0.4{ }^{\circ} \mathrm{C}$, respectively. Soil in this region is mainly chestnut soil, classified as Calcic Chernozems according to the World Reference Base for Soil Resources (Steffens et al., 2008; IUSS working group WRB, 2015), with Stipa klemenzii, Stipa Goboca, Stipa breviflora, and Stipa glareosa as the dominating species (Sui and Zhou, 2013). The alpine grassland was sampled in Gangcha (GC; $100^{\circ} 7^{\prime} \mathrm{E}, 37^{\circ} 19^{\prime} \mathrm{N}$; mean elevation $3500 \mathrm{~m}$ ) located north of the Qinghai Lake on the northeastern edge of the QinghaiTibetan Plateau. The GC site has a MAT of $0.4^{\circ} \mathrm{C}$, a MAP of $370 \mathrm{~mm}$, and a mean annual evaporation (MAE) of $607 \mathrm{~mm}$. Soils at this site are mainly Gelic Cambisol (IUSS working group WRB, 2015), with Potentilla ansrina Rosaceae, Elymus nutans Griseb, and Deyeuxia arundinacea as the dominant species.

Soils were collected by digging soil pits of $25 \mathrm{~cm} \times 25 \mathrm{~cm} \times 70 \mathrm{~cm}$ from the temperate (XLHT and KQ) and alpine (GC) sites in October 2014 and August 2015, respectively. At each site, three plots $(200 \mathrm{~m} \times 200 \mathrm{~m})$ were selected ( $>200 \mathrm{~m}$ in between) with three random soil pits (distance of $\sim 5 \mathrm{~m}$ in between) sampled within each plot. Soils from the same depth $(0-20,20-40$, and $40-60 \mathrm{~cm})$ of the three soil pits were mixed in situ for each plot, shipped back to the laboratory immediately, and stored at $4{ }^{\circ} \mathrm{C}$ before the experiment started within 1 month. As a result, each sampling site had three "true" replicates from the field for the soil column experiment. 


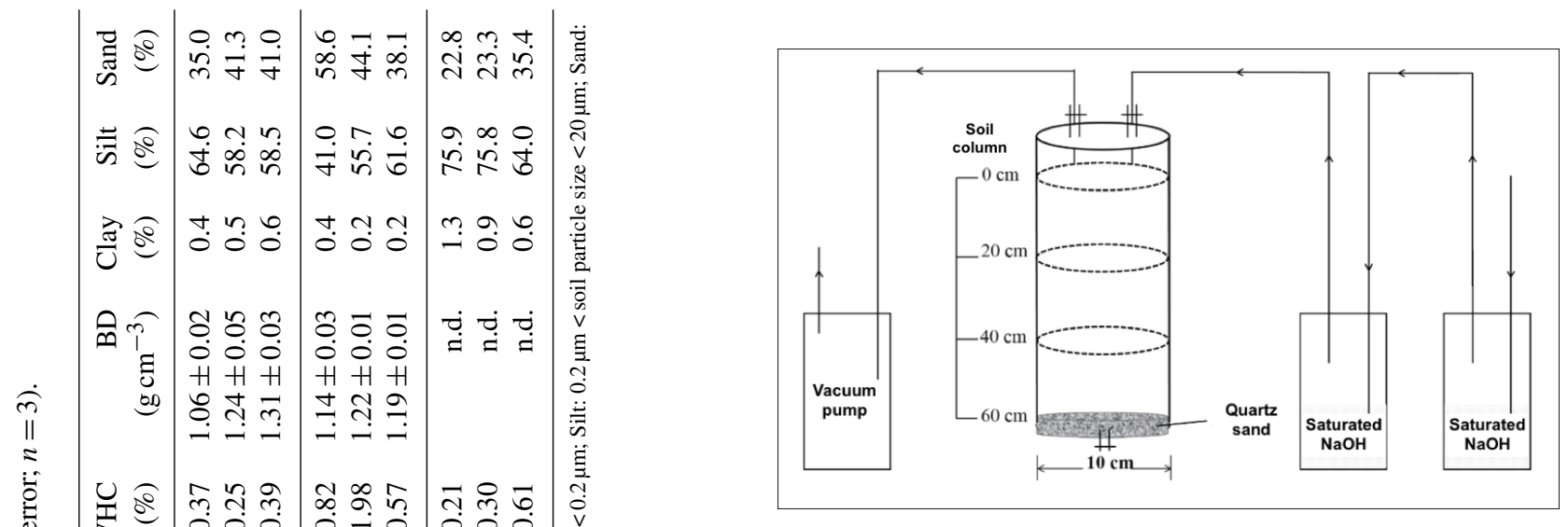

Figure 1. Design of the soil column experiment for monitoring soil respiration and leaching after simulated extreme precipitation events (EPEs).

\subsection{Soil column experiment and simulated EPEs}

For the laboratory experiment, we reconstructed soil columns of similar structures and texture under controlled conditions and used gravity to collect soil leachates. This approach is commonly used in process-related research (Hendry et al., 2001; Thaysen et al., 2014; Artiola and Walworth, 2009; Aslam et al., 2015) as it minimizes experimental errors and bias caused by unknown factors including soil heterogeneity and microbial community variations. It is also more favorable in terms of quantifying soil carbon leaching loss as it circumvents pore-water contamination by vacuum suction in the field. In particular, leachate sampling by gravity from soil columns prevents alterations to DIC concentrations, which may be caused by $\mathrm{CO}_{2}$ outgassing using vacuum suction in field studies. Artificial soil columns were constructed in the laboratory with polymethyl methacrylate frames (diameter: $10 \mathrm{~cm}$; height: $70 \mathrm{~cm}$; Fig. 1). The bottom of each column had an aperture (inner diameter: $0.6 \mathrm{~cm}$; height: $3 \mathrm{~cm}$ ) for the collection of soil leachates, and the column top was fitted with an airtight lid connected to two tubes for gas exchange and collection. Empty columns were soaked in $0.1 \mathrm{mM}$ hydrochloric acid $(\mathrm{HCl})$ solutions for $12 \mathrm{~h}$ and rinsed with distilled water before use. Column bottoms were packed with pre-cleaned quartz sand $(5 \mathrm{~cm}$ thick; soaked in $0.1 \mathrm{mM} \mathrm{HCl}$ and combusted at $450^{\circ} \mathrm{C}$ for $6 \mathrm{~h}$ before use) with a layer of nylon net (pore size: $150 \mu \mathrm{m}$; diameter: $10 \mathrm{~cm}$ ) on both sides to prevent the movement of soil particles. Subsequently, soils were passed through $2 \mathrm{~mm}$ sieves with roots removed and packed into each column at the corresponding depths (in the sequence of 40-60, 20-40, and $0-20 \mathrm{~cm}$ ). Soils were compacted gently to maintain a similar bulk density as in the field (Table 1). The water content of each soil layer was separately adjusted to $60 \%$ of the maximum water-holding capacity (Table 1) to provide an ideal moisture condition for microbial growth (Howard and Howard, 1993; Rey et al., 2005). 
There was a $10 \mathrm{~cm}$ headspace unfilled with soil for each column.

Six soil columns (one litter-amended and one nonamended column for each of the three sampling plots) were set up for each site as described above and pre-incubated for 2 weeks in the laboratory to allow for the recovery of microbial communities after disturbance. Subsequently, the leaf litter of a $\mathrm{C}_{4}$ grass, Cleistogenes squarrosa, a dominant species in the grasslands of northern China (Tian et al., 2015), was added to the surface of three columns in an amount equivalent to the aboveground biomass in the field ( $1.26 \mathrm{~g}$ for the XLHT and KQ sites and $1.59 \mathrm{~g}$ for the GC site; Bai et al., 2008). The isotopic signal of the leaf litter $\left(\delta^{13} \mathrm{C}\right.$ of $-16.2 \%$ ) allowed us to estimate the contribution of litter-derived $\mathrm{CO}_{2}$ to total soil respiration. The columns were pre-incubated again for 7 days. The basal respiration rate was measured by collecting $\mathrm{CO}_{2}$ gas in the column headspace after $4 \mathrm{~h}$ of incubation. Temperature was recorded every day during the whole incubation period $\left(23 \pm 1^{\circ} \mathrm{C}\right)$.

According to historical precipitation records (Fig. S2), more than $70 \%$ of the annual precipitation occurs from June to August in the study area, mainly in the form of two to four heavy precipitation events. Therefore, a total of three EPEs were simulated over a period of 2 months for each soil using artificial rainwater prepared according to the rainwater composition at the corresponding sites ( $\mathrm{pH}$ of 7.3; Table $\mathrm{S} 1$ in the Supplement; Tang et al., 2014; Zhang et al., 2013). A maximum rainfall intensity of $\sim 100 \mathrm{~mm}$ per precipitation event has been recorded in the past 2 decades in the study area (Fig. S2) and is predicted to increase by $18.1 \%$ in the late 21 st century in north China (Chen et al., 2012). Hence, approximately $1 \mathrm{~L}$ of rainwater (rainfall of $\sim 127 \mathrm{~mm}$ ), comparable to $30 \%$ of the MAP of the investigated sites, was added to the surface of each soil column over 3-4h at rates of one drop per second using syringes and allowed to leach through the column to be collected with a clean beaker within 12 $14 \mathrm{~h}$. The leachates were weighed, filtered through a $0.45 \mu \mathrm{m}$ PTFE syringe filter, and analyzed for dissolved organic carbon (DOC) and dissolved inorganic carbon (DIC) concentrations immediately. To monitor soil respiration every 1-2 days following each EPE, soil columns were first aerated for $1 \mathrm{~h}$ using $\mathrm{CO}_{2}$-depleted air that had been passed through saturated sodium hydroxide $(\mathrm{NaOH})$ solutions (twice; Fig. 1) and then incubated for $4 \mathrm{~h}$ with lids closed. $\mathrm{CO}_{2}$ gas in the column headspace was collected by gastight syringes for the subsequent measurement. After the collection of $\mathrm{CO}_{2}$ gas, the lids were open to allow for exchange with the ambient air. Soil respiration was monitored for 30 days after the first EPE and observed to stabilize approximately on the 20th day (Fig. S3). Hence, the first, second, and third EPEs were conducted on the 1st, 31st, and 51st day of incubation, and the $\mathrm{CO}_{2}$ measurement was conducted for approximately 30, 20, and 20 days after the first, second, and third EPEs, respectively. Basal respiration was considered to be represented by the stabilized respiration rate at the end of each EPE cycle.
In addition, due to constrained time and logistic reasons, the soil respiration after the second EPE in the KQ soils was not monitored, and the cumulative respiration after the second EPE was calculated as the average respiration after the first and third EPEs in the KQ soils.

\subsection{Sample analyses}

Soil $\mathrm{pH}$ was measured at a soil: water ratio of $1: 2.5(w: v)$ using a pH meter (Sartorius PB-10). Soil texture was examined by laser diffraction using a Malvern Mastersizer 2000 (Malvern Instruments Ltd., UK) after the removal of organic matter and calcium carbonates. Soil field water content was determined by the difference between moist and dried soils (dried at $105^{\circ} \mathrm{C}$ for $8 \mathrm{~h}$ ). Maximum water-holding capacity was estimated by weighing soils before and after the removal of redundant water from fully soaked soils (in water for $8 \mathrm{~h}$ ). For SOC analysis, dried soils were decarbonated by exposure to concentrated $\mathrm{HCl}$ vapor for $72 \mathrm{~h}$, followed by saturated $\mathrm{NaOH}$ solutions for $48 \mathrm{~h}$ to neutralize extra $\mathrm{HCl}$, and then dried at $45^{\circ} \mathrm{C}$. Total soil carbon, SOC (after decarbonation), and nitrogen $(\mathrm{N})$ contents were measured by combustion using an elemental analyzer (Vario EL III; Elementar, Hanau, Germany). SIC was calculated as the difference between total carbon and SOC contents. Small aliquots of the soil leachates were analyzed immediately on a Multi N / C 3100-TOC/TN Analyzer (Analytik Jena, Germany) for DIC and DOC concentrations (with the latter acidified to $\mathrm{pH}<2$ with concentrated $\mathrm{HCl}$ before analysis). It should be mentioned that the DIC concentration may vary due to exchanges between dissolved and atmospheric $\mathrm{CO}_{2}$ during leachate collection. However, the potential contribution from this process was $<7 \%$ owing to the low proportions of dissolved $\mathrm{CO}_{2}$ in total DIC of our samples (Table S2) as calculated according to Ran et al. (2015). $\mathrm{CO}_{2}$ concentration in the soil column headspace was determined by a gas chromatograph (Agilent 7890A, USA) coupled with a flame ionization detector (FID).

To examine the contribution of SOC- and litter-derived carbon to soil respiration, the $\delta^{13} \mathrm{C}$ values of $\mathrm{SOC}$ and $\mathrm{CO}_{2}$ gas were determined on an isotope ratio mass spectrometer (Deltaplus XP; Thermo, Germany) with a precision of $\pm 0.2 \%$. To estimate the contribution of SOC degradation to leached DIC, the $\delta^{13} \mathrm{C}$ values of DIC were determined on a Picarro isotopic $\mathrm{CO}_{2}$ analyzer equipped with an automated DIC sample preparation system (AutoMate) based on a wavelength-scanned cavity ring-down spectroscopy technique (Picarro AM-CRDS, USA). The precision for the DIC$\delta^{13} \mathrm{C}$ measurement was $\pm 0.3 \%$. Due to budget constraints and logistic reasons, we only measured the $\delta^{13} \mathrm{C}$ of the respired $\mathrm{CO}_{2}$ in the $\mathrm{GC}$ soils during the first EPE and the leached DIC in the XLHT soils. 


\subsection{Data analysis and statistics}

The relative contribution of litter- and SOC-derived $\mathrm{CO}_{2}$ to total respired $\mathrm{CO}_{2}$ in the litter-amended soils was estimated using the following mass balance model:

$$
\begin{gathered}
f_{\text {litter-derived }}+f_{\text {SOC-derived }}=1, \\
f_{\text {litter-derived }} \times \delta^{13} \mathrm{C}_{\text {litter-derived }}+f_{\text {SOC-derived }} \\
\times \delta^{13} \mathrm{C}_{\text {SOC-derived }}=\delta^{13} \mathrm{C}_{\text {respired-CO }},
\end{gathered}
$$

where $f_{\text {litter-derived }}$ and $f_{\text {SOC-derived }}$ are the proportion of litter- and SOC-derived $\mathrm{CO}_{2}$ in the total respired $\mathrm{CO}_{2}$; $\delta^{13} \mathrm{C}_{\text {litter-derived }}$ is the $\delta^{13} \mathrm{C}$ value of litter-derived $\mathrm{CO}_{2}$, equivalent to $-16.25 \% ; \delta^{13} \mathrm{C}_{\text {SOC-derived }}$ is the $\delta^{13} \mathrm{C}$ value of SOCderived $\mathrm{CO}_{2}$, which assumes the same value as that in the non-amended soils at the beginning of incubation $(-23.1 \%$ o) according to Cerling et al. (1991); and $\delta^{13} \mathrm{C}_{\text {respired- } \mathrm{CO}_{2}}$ is the measured $\delta^{13} \mathrm{C}$ of respired $\mathrm{CO}_{2}$.

Similarly, the relative contribution of lithogenic carbonate and biogenic DIC derived from SOC degradation to leached DIC was assessed according to the following isotopic mass balance model:

$$
\begin{aligned}
& f_{\text {carbonate }}+f_{\text {biogenic-DIC }}=1, \\
& f_{\text {carbonate }} \times \delta^{13} C_{\text {carbonate }}+f_{\text {biogenic-DIC }} \\
& \times \delta^{13} C_{\text {biogenic-DIC }}=\delta^{13} C_{D I C},
\end{aligned}
$$

where $f_{\text {carbonate }}$ and $f_{\text {biogenic-DIC }}$ are the proportion of carbonate and biogenic DIC in total DIC; $\delta^{13} \mathrm{C}_{\text {carbonate }}$ is the $\delta^{13} \mathrm{C}$ value of soil carbonate, equivalent to $0 \%$ (Edwards and Saltzman, 2016); and $\delta^{13} \mathrm{C}_{\text {biogenic-DIC }}$ is the $\delta^{13} \mathrm{C}$ value of biogenic carbonate and bicarbonate derived from the dissolution of $\mathrm{CO}_{2}$ produced by $\mathrm{SOC}$ degradation, which is estimated to shift by approximately $8 \%$ compared with the $\delta^{13} \mathrm{C}$ value of soil-respired $\mathrm{CO}_{2}(-24 \%$ o here $)$ due to isotope fractionation during $\mathrm{CO}_{2}$ dissolution (Zhang et al., 1995). Hence, $\delta^{13} \mathrm{C}_{\text {biogenic-DIC }}$ is estimated to be $-16 \%$. The $\delta^{13} \mathrm{C}_{\text {DIC }}$ value is the measured $\delta^{13} \mathrm{C}$ signature of leached DIC. The isotopic fractionation of leached DIC due to $\mathrm{CO}_{2}$ loss in an open system is insignificant when the partial pressure of $\mathrm{CO}_{2}\left(p \mathrm{CO}_{2}\right)$ in the solution is lower than twice that of the surrounding atmosphere (Hendy, 1971; Doctor et al., 2008). In the present study, $p \mathrm{CO}_{2}$ in the XLHT leachates was low $(\sim 400 \mu \mathrm{atm}$ assuming alkalinity equals to DIC concentration; Table S2) due to its high $\mathrm{pH}$, low soil respiration, and dilution of dissolved $\mathrm{CO}_{2}$ under an EPE. Thus, we considered the influence of $\mathrm{CO}_{2}$ outgassing on the $\delta^{13} \mathrm{C}$ of leached DIC to be negligible.

EPE-induced $\mathrm{CO}_{2}$ release via respiration was assessed following two steps. First, cumulative respiration during the first 20 days after each EPE (until respiration rate stabilized) was calculated. Second, the difference between the measured cumulative respiration and that estimated using the stabilized basal respiration rate after each EPE was calculated as the EPE-induced $\mathrm{CO}_{2}$ release.
Independent sample $T$ tests (group size $=2$ ) and one-way ANOVA analysis (group size $>2$ ) were used to compare the dissolved carbon concentrations and fluxes among different columns. Linear regression analysis was used to assess correlations between leachate carbon flux and influencing factors (carbon content, soil $\mathrm{pH}$, soil texture, etc.). All these analyses were performed using IBM SPSS Statistics 22. Differences and correlations are considered to be significant at a level of $p<0.05$.

\section{Results and discussion}

\subsection{Bulk properties of grassland soil samples}

In the investigated grassland soils, SOC represented 59$99 \%$ of soil carbon and exhibited $\delta^{13} \mathrm{C}$ values typical of $\mathrm{C}_{3}$ plant inputs (ranging from -24.1 to $-26.3 \%$; Table 1 ). The XLHT soil had much lower SOC and nitrogen $(\mathrm{N})$ contents than the KQ and GC soils despite a similar soil texture $(p<0.05$; Table 1$)$. The SOC : $\mathrm{N}$ ratio was also lowest in XLHT (7.09-8.03), indicating a more decomposed state of soil organic matter (Weiss et al., 2016). Conversely, the SIC content was highest in XLHT and lowest in KQ, in line with soil $\mathrm{pH}$ variations at these sites, i.e., lowest $\mathrm{pH}$ in $\mathrm{KQ}$ and highest in XLHT. This correlation of SIC with soil pH is consistent with the results of Shi et al. (2012), showing that $\mathrm{pH}$ is the most important factor controlling SIC variation across the Mongolian and Tibetan grasslands. In terms of depth variations, soils became coarser with depth in XLHT and GC, but became finer with increasing depth in KQ. The SOC and N contents decreased with depth in all soils due to declining plant inputs $(p<0.05$; Table 1$)$, while the SOC: $\mathrm{N}$ ratio remained relatively similar (except a small decrease with depth in XLHT). By contrast, XLHT and GC soils showed an increasing SIC content with depth $(p<0.05$; Table 1$)$ because SIC, with a good solubility, is prone to leaching from the topsoil and subsequently precipitates in the deeper soil (Mi et al., 2008; Tan et al., 2014). The KQ soil, showing an almost neutral $\mathrm{pH}$, had an invariant SIC content and $\mathrm{pH}$ with depth. Overall, the varied properties (including SOC, SIC, pH, etc.) of these soils allowed us to compare the effects of EPEs on soil respiration and leaching processes in different grassland soils.

\subsection{EPE-induced changes to soil respiration}

Shortly after each simulated EPE, soil respiration was similar to or lower than basal respiration (Fig. S3). The latter case may be attributed to hypoxic conditions induced by water saturation during EPEs (Hartnett and Devol, 2003; Jessen et al., 2017). Subsequently, soil respiration increased and peaked after approximately 1 week due to the recovery of microbial activity with improved soil aeration (Borken and Matzner, 2009). It then decreased to a constant level approximately 20 days after each EPE (Fig. S3). The transient increase 


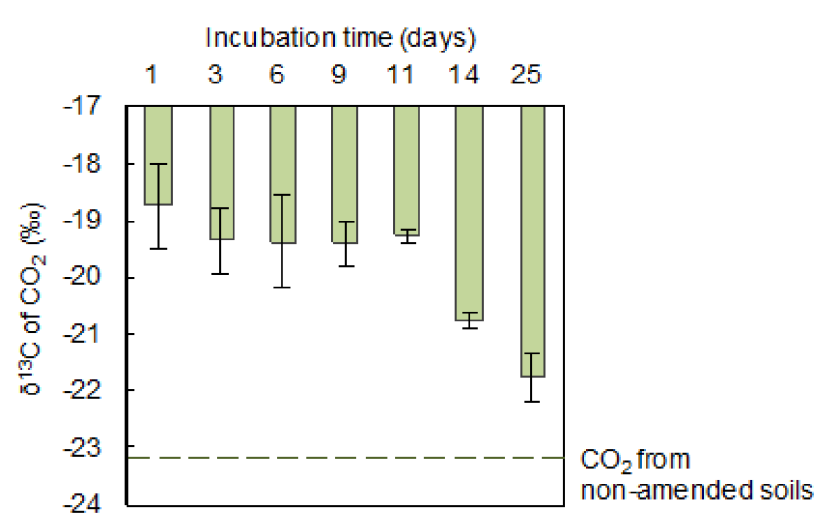

Figure 2. The $\delta^{13} \mathrm{C}$ values of respired $\mathrm{CO}_{2}$ in the litter-amended Gangcha (GC) soils after the first extreme precipitation event (EPE). Mean values are shown with standard error $(n=3)$.

in respiration was consistent with the "Birch effect" (Birch, 1964), i.e., a pulse of soil respiration after rewetting events due to resuscitation of microorganisms and improved diffusive transport of substrate and extracellular enzymes (Borken and Matzner, 2009; Navarro-García et al., 2012; Placella et al., 2012). The maximum soil respiration rates were 40.6 and $37.3 \mathrm{mg} \mathrm{C} \mathrm{m}^{-2} \mathrm{~h}^{-1}$ after EPEs in the non-amended KQ and GC soils, respectively. These rates were significantly higher than in the XLHT soil (13.7 $\left.\mathrm{mg} \mathrm{C}^{-2} \mathrm{~h}^{-1}\right)$, likely related to the higher SOC content in the former soils. The maximum specific soil respiration rates normalized to SOC were 2.2, 2.6, and $2.0 \mu \mathrm{g} \mathrm{Cg}^{-1} \mathrm{SOC} \mathrm{h}^{-1}$ in the non-amended GC, KQ, and XLHT soils, respectively. Therefore, SOC degradability was quite similar in the alpine and temperate grassland soils.

Total respired $\mathrm{CO}_{2}$ was higher in the litter-amended than non-amended soils before and after EPEs (Fig. S6). The cumulative respired $\mathrm{CO}_{2}$ amounts in the litter-amended XLHT, $\mathrm{KQ}$, and GC soils were $16.7,54.8$, and $44.6 \mathrm{~g} \mathrm{C} \mathrm{m}^{-2}$ during three EPEs, which is 20, 22, and $15 \%$ higher than the non-amended soils, respectively. Due to the wide presence of litter coverage in our studied soils, the litter effect on soil respiration should be considered when estimating carbon budgets for these grassland soils. The higher total respired $\mathrm{CO}_{2}$ in litter-amended soils might be caused by one or both of the following: (1) the degradation of labile components in the fresh litter and/or (2) induced priming effects due to the addition of an easily available energy source (Fröberg et al., 2005; Ahmad et al., 2013). To distinguish the influences of the above two factors on total respired $\mathrm{CO}_{2}$ and further differentiate the contribution of litter $\left(\mathrm{C}_{4}\right)$ and SOC $\left(\mathrm{C}_{3}\right)$ to the respired $\mathrm{CO}_{2}$, we examined the $\delta^{13} \mathrm{C}$ values of $\mathrm{CO}_{2}$ evolved from the $\mathrm{GC}$ soils after the first EPE. On the first day after EPE, $\mathrm{CO}_{2}$ from the non-amended and litteramended GC soils had a $\delta^{13} \mathrm{C}$ value of -23.1 and $-18.7 \%$, respectively. The latter was close to the $\delta^{13} \mathrm{C}$ signature of the added litter $(-16.25 \%$ o). Using the two-endmember mix- ing model of Eqs. (1) and (2), we calculated that litter contributed $\sim 64 \%$ of the respired $\mathrm{CO}_{2}$ in the litter-amended GC soils. However, along with the consumption of labile carbon in litter, the $\delta^{13} \mathrm{C}$ signature of $\mathrm{CO}_{2}$ decreased from $-18.7 \%$ on day 1 to $-21.8 \%$ on day 25 after an EPE in the litter-amended soils (Fig. 2). Accordingly, the proportion of litter-derived $\mathrm{CO}_{2}$ decreased from 64 to $20 \%$. The litterderived $\mathrm{CO}_{2}$ flux in litter-amended GC soils was estimated to range from 7.0 to $17.5 \mathrm{mg} \mathrm{C} \mathrm{m}^{-2} \mathrm{~h}^{-1}$, while the SOCderived $\mathrm{CO}_{2}$ flux increased from 6.2 to $15.7 \mathrm{mg} \mathrm{C} \mathrm{m}^{-2} \mathrm{~h}^{-1}$ after the first EPE (Fig. S4). Compared with the SOC-derived $\mathrm{CO}_{2}$ flux in non-amended GC soils (ranging from 17.2 to $27.1 \mathrm{mg} \mathrm{C} \mathrm{m}^{-2} \mathrm{~h}^{-1}$ ), litter addition had a negative priming effect on the degradation of native SOC while increasing total respiration through labile litter degradation.

Using the data shown in Figs. S3 and S5, we calculated that total EPE-induced $\mathrm{CO}_{2}$ release during three EPEs was higher in the KQ and GC soils than in the XLHT soil $(p<0.05$; Fig. 3a) with a lower SOC content and a lower SOC : $\mathrm{N}$ ratio (Table 1). However, the specific EPE-induced $\mathrm{CO}_{2}$ release normalized to SOC content showed no significant difference in the non-amended soils among the three sites (Fig. 3b), indicating that a similar proportion of SOC $(\sim 4 \%)$ was subject to EPE-induced $\mathrm{CO}_{2}$ release in the alpine and temperate grassland soils (Fig. 3b). The total EPEinduced $\mathrm{CO}_{2}$ release was significantly higher in the litteramended KQ soils than the non-amended ones. Besides the availability of labile OC provided by litter, the higher total EPE-induced $\mathrm{CO}_{2}$ in litter-amended $\mathrm{KQ}$ soils might be related to its relatively lower soil $\mathrm{pH}(\sim 7.7)$ that facilitates the release rather than the dissolution of respired $\mathrm{CO}_{2}$ (from both SOC and litter mineralization) in soil solution. In addition, KQ has the highest mean sand content $(46.9 \%)$ among the three soils (Table 1), i.e., the least possible mineral protection on labile OC dissolved from the litter, and this benefits the transport and mineralization of labile OC that meanwhile might induce positive priming effects on the SOC mineralization. We therefore conclude that the KQ soil, with a coarser texture and a lower $\mathrm{pH}$ (Table 1), may have provided less sorptive protection for the labile DOC components after EPEs (Kell et al., 1994; Nelson et al., 1994), allowed less dissolution of the respired $\mathrm{CO}_{2}$, and hence showed a more responsive respiration to the precipitation events. Consequently, we deduced that the availability of labile organic carbon, soil texture, and $\mathrm{pH}$ are important factors influencing the total EPE-induced $\mathrm{CO}_{2}$ release in temperate and alpine grassland soils.

\subsection{EPE-induced leaching of soil carbon}

During the first EPE, a total of $0.57,0.56$, and $0.73 \mathrm{~L}$ of leachates were collected from the XLHT, KQ, and GC soils, respectively. The leachate increased to $0.71,0.94$, and $0.87 \mathrm{~L}$ during the second EPE and was 0.69, 0.83, and 0.89 L during the third EPE, respectively (Fig. 4). Soil water content 

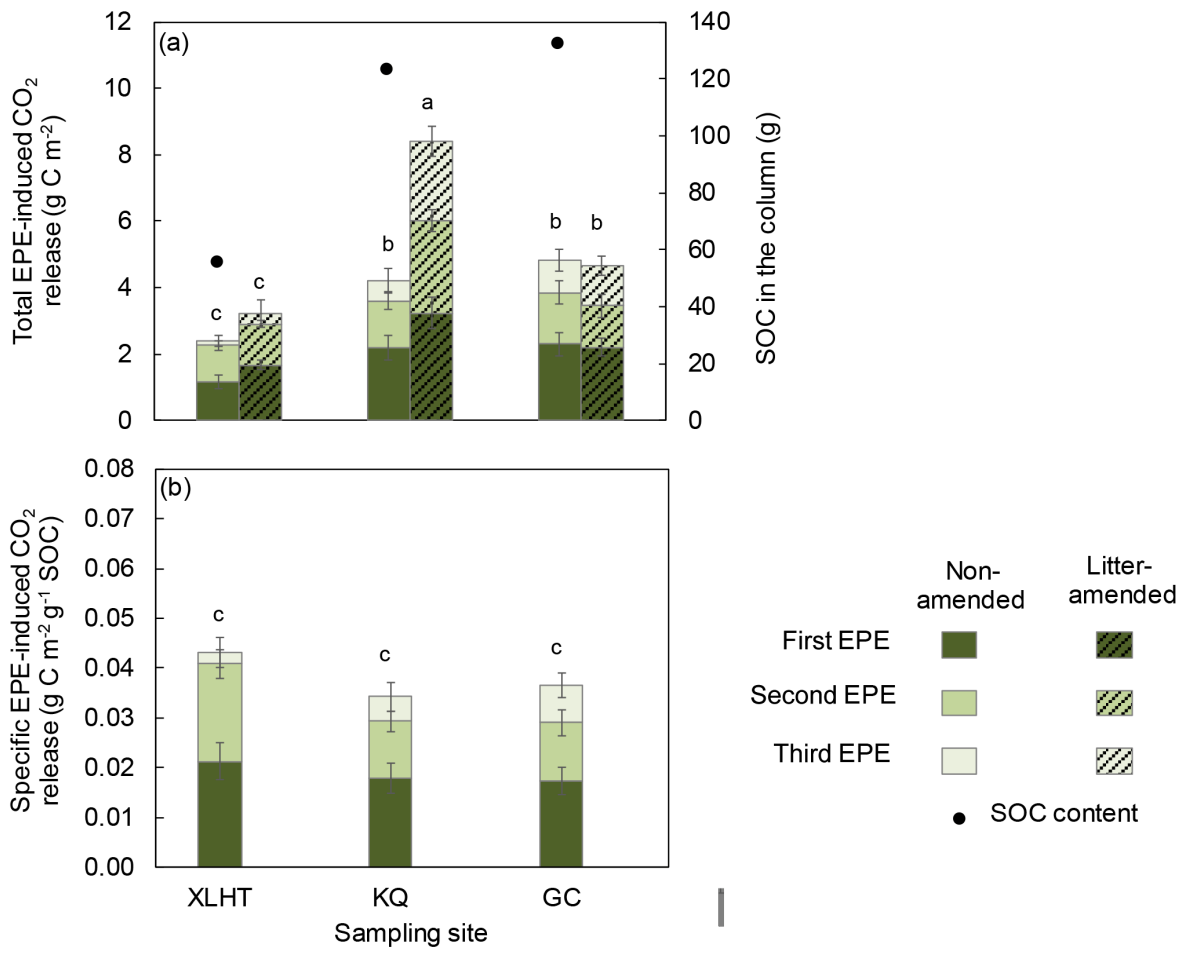

Figure 3. Total (a) and specific (b) EPE-induced $\mathrm{CO}_{2}$ release in the litter-amended and non-amended grassland soils during three EPEs. Mean values are shown with standard deviation $(n=3)$. Lowercase letters $(\mathbf{a}, \mathbf{b}, \mathbf{c})$ indicate significantly different levels among the litter-amended and non-amended soils determined by Duncan's multiple range test (one-way ANOVA, $p<0.05$ ).

was set to $\sim 60 \%$ of maximum WHC before the first EPE, and leaching did not occur until soil water reached saturation. Therefore, the leachate volume was lowest during the first EPE and similar for the second and third EPEs. There were some variations in the volume of leachates from different soils, possibly related to preferential flows created during EPEs in the soil columns (McGrath et al., 2009) and water evaporation between EPEs. DIC was the main form of carbon in the leachates from the alkaline soils with a high SIC content (XLHT and GC) but low from the KQ soil with a neutral $\mathrm{pH}$ and low SIC content (Fig. 4). The resulting DIC flux was much higher for the XLHT soils $\left(\sim 21.3 \mathrm{~g} \mathrm{C} \mathrm{m}^{-2}\right)$ than the other two $\left(2.9 \mathrm{~g} \mathrm{C} \mathrm{m}^{-2}\right.$ for $\mathrm{KQ}$ and $7.4 \mathrm{~g} \mathrm{C} \mathrm{m}^{-2}$ for GC soils) during three EPEs, equivalent to 5 times its DOC flux (3.8-4.2 $\mathrm{g} \mathrm{C} \mathrm{m}^{-2}$; Fig. 4). In contrast, DIC flux in the KQ soils was only one-third of its DOC flux during EPEs. The form of leached carbon was mainly linked to the amount of SOC and SIC in the columns (shown in Fig. S5).

Litter amendment did not increase DOC fluxes in any of the investigated soils but increased DIC fluxes leached from the KQ soil during the second and third EPEs and from the GC soil during the second EPE ( $p<0.05$; Fig. $4 \mathrm{~b}-\mathrm{c})$. We postulate that while litter contribution to DOC was minor, $\mathrm{CO}_{2}$ derived from litter degradation contributed to dissolved $\mathrm{CO}_{2}$ in soils and hence increased DIC in the leachates (Monger et al., 2015). This effect was not evident during the first EPE when litter decomposition just started and was not significant for the third EPE in the GC soil due to a high sample variability associated with the litter-amended soil (Fig. 4c). Due to the high SIC content in the XLHT soils ( $38.15 \mathrm{~g}$ per column) and the low litter OC amendment ( $0.7 \mathrm{~g}$ per column), there was no significant difference in DIC fluxes between the non-amended and litter-amended XLHT soils (Fig. 4a). However, for the KQ soil having a relatively low SIC content similar to the added litter OC $(0.7 \mathrm{~g}$ per column; Table 1), litter amendment had a significant effect on the DIC flux $(p<0.05)$, increasing by $21 \pm 13$ and $15 \pm 7 \%$ relative to the non-amended KQ soils during the second and third EPEs, respectively. There was also a $30 \pm 19 \%$ increase in the DIC flux from the litter-amended GC soils relative to its non-amended counterpart during the second EPE. Therefore, litter amendment had a significant influence on DIC fluxes from soils with a relatively low SIC content (KQ and GC) under EPEs compared with the high-SIC XLHT soil.

Between different EPEs, leachate DOC fluxes did not vary in any of the investigated soils. By comparison, DIC fluxes increased in the XLHT soil from $4.5 \mathrm{~g} \mathrm{C} \mathrm{m}^{-2}$ after the first EPE to $9.0 \mathrm{~g} \mathrm{C} \mathrm{m}^{-2}$ after the third EPE ( $p<0.01$; Fig. 4$)$. This increase may be caused by (i) an increased contribution of SOC degradation to soil DIC and/or (ii) an elevated dissolution of soil carbonates induced by higher soil $\mathrm{CO}_{2}$ concentrations with repeated EPEs (Gulley et al., 2014; Ren et 
(a) XLHT

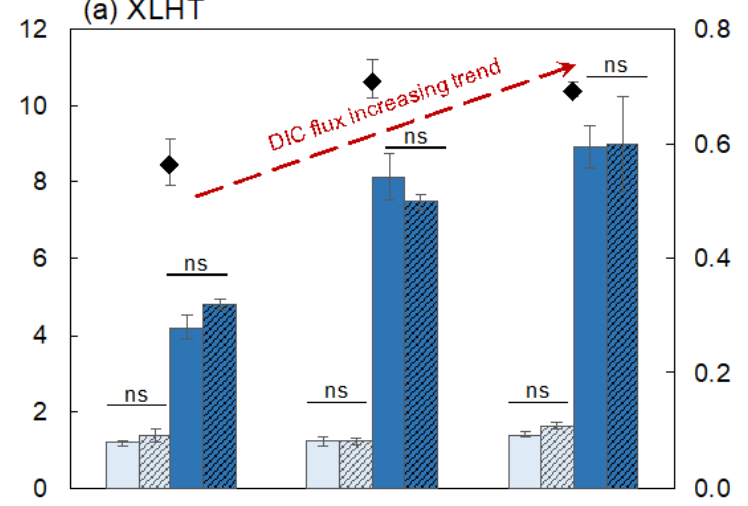

(b) $K Q$

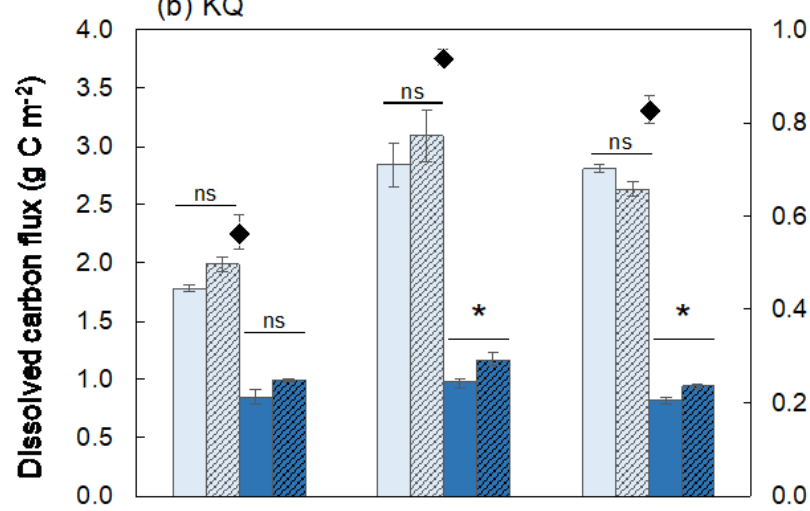

(c) GC

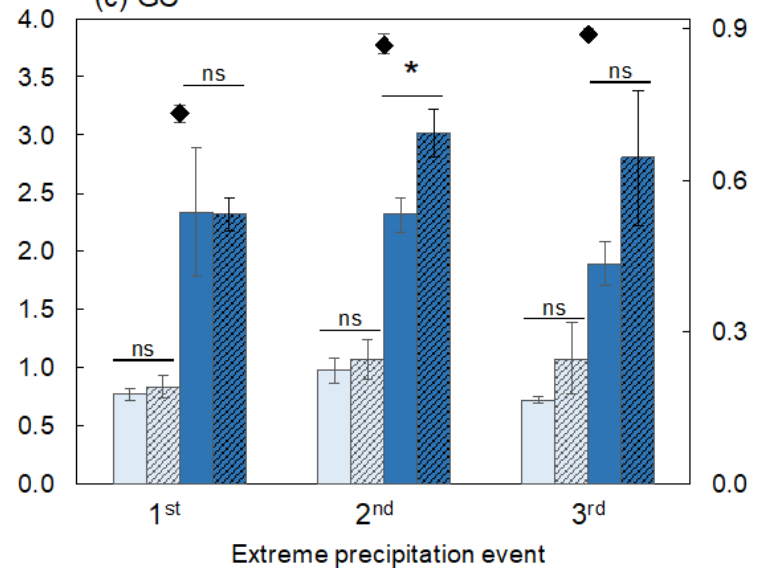

己
0
$\frac{0}{0}$
$\frac{1}{0}$
$\frac{\pi}{0}$
$\frac{1}{4}$
0
0
$\frac{1}{5}$
$\frac{1}{0}$
$>$
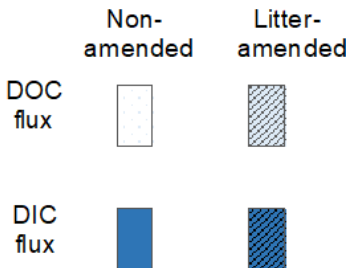

- Volume of leachate

Figure 4. Fluxes of dissolved organic carbon (DOC) and dissolved inorganic carbon (DIC) and volume of leachates from soil columns after extreme precipitation events (EPEs). Mean values are shown with standard error $(n=3)$. The * and "ns" denote significant and no difference between the litter-amended and non-amended soils determined by independent sample $T$ tests, respectively $(p<0.05)$.

al., 2015). To evaluate these contributions, the $\delta^{13} \mathrm{C}$ values of DIC were measured for the non-amended XLHT soil. The $\delta^{13} \mathrm{C}$ of leached DIC ranged from -10.0 to $-6.6 \%$ during the first EPE. Based on the isotopic mass balance of Eqs. (3) and (4), lithogenic carbonate (with a $\delta^{13} \mathrm{C}$ value of $0 \%$ ) contributed $51 \%$ to the leached DIC, while biogenic DIC produced by SOC degradation contributed $48 \%$ (Fig. 5). The $\delta^{13} \mathrm{C}$ value of leached DIC decreased to -12.3 and $-13.5 \%$ o during the second and third EPEs, corresponding to a contribution of 77 and $84 \%$ by biogenic sources in the total DIC, respectively (Fig. 5). These results confirm our previous hypothesis that SOC decomposition contributed significantly to soil DIC fluxes. Combined with the total flux rate, we calculated that both lithogenic and biogenic DIC fluxes were $\sim 2.1 \mathrm{~g} \mathrm{C} \mathrm{m}^{-2}$ in the first EPE. Subsequently, lithogenic DIC flux decreased to $\sim 1.3 \mathrm{~g} \mathrm{C} \mathrm{m}^{-2}$, while biogenic DIC flux increased to $7.6 \mathrm{~g} \mathrm{C} \mathrm{m}^{-2}$ in the third EPE. This demonstrates that the increased DIC flux with repeated EPEs was mainly derived from an increased contribution of SOC mineralization. Interestingly, increasing DIC fluxes with repeated EPEs 


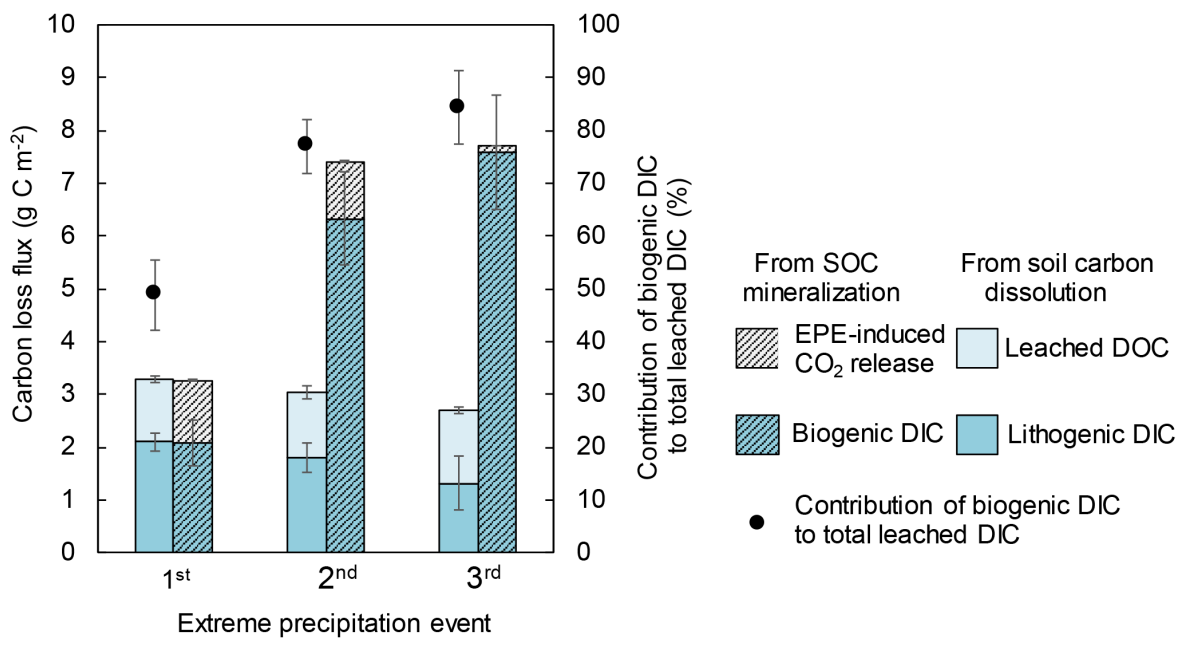

Figure 5. Carbon loss fluxes from soil organic carbon (SOC) mineralization in the non-amended XLHT soils. Fluxes include EPE-induced $\mathrm{CO}_{2}$ release and leaching of biogenic dissolved inorganic carbon (DIC), dissolved organic carbon (DOC), and lithogenic DIC. Mean values are shown with standard error $(n=3)$.

were not observed in the KQ and GC soils (Fig. 4) despite their higher SOC contents (Table 1) and $\mathrm{CO}_{2}$ release rates (Fig. S3). Given that the XLHT soil had the highest soil pH, the high alkalinity may have favored the retention of respired $\mathrm{CO}_{2}$ in the soil solution compared with the other soils (Parsons et al., 2004; Yates et al., 2013; Liu et al., 2015), leading to its high contribution to DIC fluxes.

Regardless of its source, the EPE-induced leaching loss of inorganic carbon was 31.5 and $10.6 \mu \mathrm{g} \mathrm{DIC} \mathrm{g}^{-1}$ soil from the alkaline XLHT and GC soils, respectively, which is approximately 3 and 5 times higher than the corresponding DOC leaching loss (5.9 and $3.9 \mu \mathrm{gOC}^{-1}$ soil, respectively). However, the KQ soil had a relatively lower EPE-induced DIC loss $\left(4.4 \mu \mathrm{g}_{\text {DIC }}{ }^{-1}\right.$ soil) than the DOC leaching loss (11.6 $\mu \mathrm{g} \mathrm{DOC}^{-1}$ soil) mainly due to its lower initial SIC content and relatively neutral soil $\mathrm{pH}$ value. Hence, total DIC (biogenic DIC + lithogenic DIC) was the main form of soil carbon loss in alkaline soils during EPEs. When the source of the leached DIC is taken into account, the dissolution of $\mathrm{CO}_{2}$ produced by SOC mineralization (biogenic DIC) constituted more than half of the leached DIC (at least from the XLHT soils; Fig. 5), whose contribution increased with recurring EPEs (Fig. 5). This implies that SOC mineralization during the three EPEs was underestimated by approximately a factor of 8 when measured as $\mathrm{CO}_{2}$ gas flux from the soil into the column headspace only (Fig. 5). In addition, DIC loss exclusively resulting from SIC dissolution or weathering was also a significant fraction of soil carbon loss, equivalent to $219 \%$ SOC loss in the form of EPE-induced $\mathrm{CO}_{2}$ during EPEs (Fig. 5). These results collectively corroborate the evidence that inorganic carbon loss is the main form of soil carbon loss in alkaline soils during EPEs.
As for the influencing factors on soil carbon leaching loss, the DIC flux was positively correlated with the amount of SIC in the soil columns and soil $\mathrm{pH}(p<0.05$; Fig. $6 \mathrm{a}-\mathrm{b})$. These two relationships may be self-correlated due to a positive relationship between soil pH and SIC (Liu et al., 2016). By comparison, DOC flux was linked with the amount of SOC in the soil columns, but decreased with an increasing content of silt and clay ( $p<0.05$; Fig. $6 c)$. This may be explained by the stronger retention of SOC on small-sized particles with more sorption sites (Barré et al., 2014; Mayer, 1994). Interestingly, neither DOC nor DIC fluxes showed any significant relationships with the volume of leachates during EPEs (Fig. 6e-f). This indicates that we used a sufficient amount of precipitation in this study to "scavenge" dissolved carbon from soils, and hence these fluxes represent the soil carbon leaching potential under EPEs. Overall, total soil carbon loss through leaching under EPEs was positively related to soil $\mathrm{pH}$ values ( $p<0.05$; Fig. $6 \mathrm{~d}$ ), suggesting that soil $\mathrm{pH}$ is a critical factor determining the magnitude of soil carbon loss under EPEs.

\subsection{Main pathways of grassland soil carbon loss under EPEs}

In this study, EPE-induced soil carbon loss was composed of three parts: leachate DIC including lithogenic and biogenic DIC, leached DOC, and EPE-induced $\mathrm{CO}_{2}$ emission into the column headspace. Total DIC and DOC fluxes accounted for 90, 62, and $68 \%$ of EPE-induced total loss at XLHT, KQ, and GC, respectively, representing the major pathway of soil carbon loss in these grassland soils under EPEs. Soil carbon leaching fluxes were 25.3, 10.4, and $10.1 \mathrm{~g} \mathrm{C} \mathrm{m}^{-2} \mathrm{yr}^{-1}$ in XLHT, KQ, and GC soils during three EPEs, respectively, with DIC as the dominant form in XLHT 

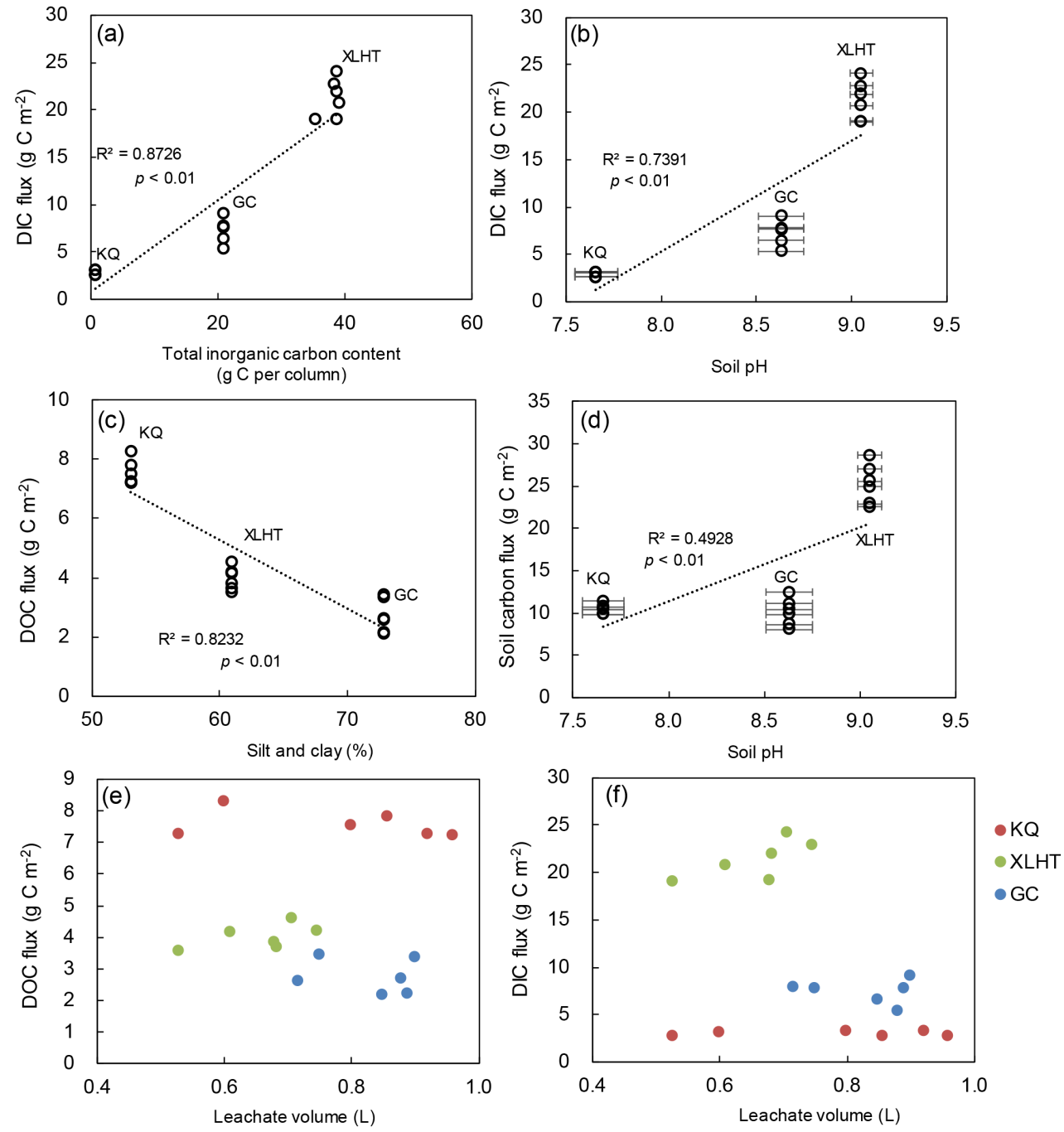

Figure 6. Relationship of dissolved inorganic carbon (DIC) and dissolved organic carbon (DOC) fluxes with soil properties: (a) DIC flux with total inorganic carbon in the soil columns; (b) DIC flux with soil pH; (c) DOC flux with silt and clay content of soils; (d) total soil carbon flux with soil pH; (e) DOC flux with leachate volume; (f) DIC flux with leachate volume. Mean pH values are shown with standard error $(n=3)$.

and GC soils. While DIC fluxes found for the KQ and GC soils generally fell within the range reported for grassland soils (1.3-47.8 $\mathrm{g} \mathrm{C} \mathrm{m}^{-2} \mathrm{yr}^{-1}$; Parfitt et al., 1997; Brye et al., 2001; Kindler et al., 2011), the XLHT soil had a DIC flux higher than the majority $(>50 \%)$ of the reported values (Fig. 7). This may be attributed to the higher SIC content and stronger dissolution of respired $\mathrm{CO}_{2}$ in the XLHT soils due to its higher soil $\mathrm{pH}(9.1 \pm 0.1)$ relative to other grassland soils (pH: 5.4-7.5; Kindler et al., 2011) and the high intensity of our simulated EPEs (precipitation: $40 \mathrm{~mm} \mathrm{~h}^{-1}$ ). Nonetheless, the DIC fluxes in grassland soils reported in this study and elsewhere (Brye et al., 2001; Kindler et al., 2011) were significantly higher than in forest and cropland ecosystems ( $p<0.05$; Rieckh et al., 2014; Lentz and Lehrsch, 2014; Gerke et al., 2016; Herbrich et al., 2017; Siemens et al., 2012;
Walmsley et al., 2011; Wang and Alva, 1999; Kindler et al., 2011), highlighting the importance of leaching as a major pathway of soil carbon loss in grasslands. By contrast, DOC fluxes in this study $\left(4.8 \pm 2.5 \mathrm{~g} \mathrm{C} \mathrm{m}^{-2}\right)$ were lower than most of the reported values in forest and grassland ecosystems due to the low SOC contents in our soils (Fig. 7).

Net ecosystem production (NEP) in the temperate steppe of Inner Mongolia (XLHT and KQ) is $8.7 \mathrm{~g} \mathrm{C} \mathrm{m}^{-2} \mathrm{yr}^{-1}$ (Sui and Zhou, 2013). While the EPE-induced $\mathrm{CO}_{2}$ release $\left(2.8 \pm 0.6\right.$ and $\left.6.3 \pm 3.0 \mathrm{~g} \mathrm{C} \mathrm{m}^{-2}\right)$ accounted for 32 and $72 \%$ of the NEP at XLHT and KQ, respectively, soil carbon leached during three EPEs was equivalent to 290 and $120 \%$ of NEP, with total DIC loss accounting for 244 and $33 \%$, respectively. It is worth mentioning that biogenic DIC loss $\left(16.0 \pm 3.4 \mathrm{~g} \mathrm{C} \mathrm{m}^{-2}\right)$ caused by SOC degradation ac- 


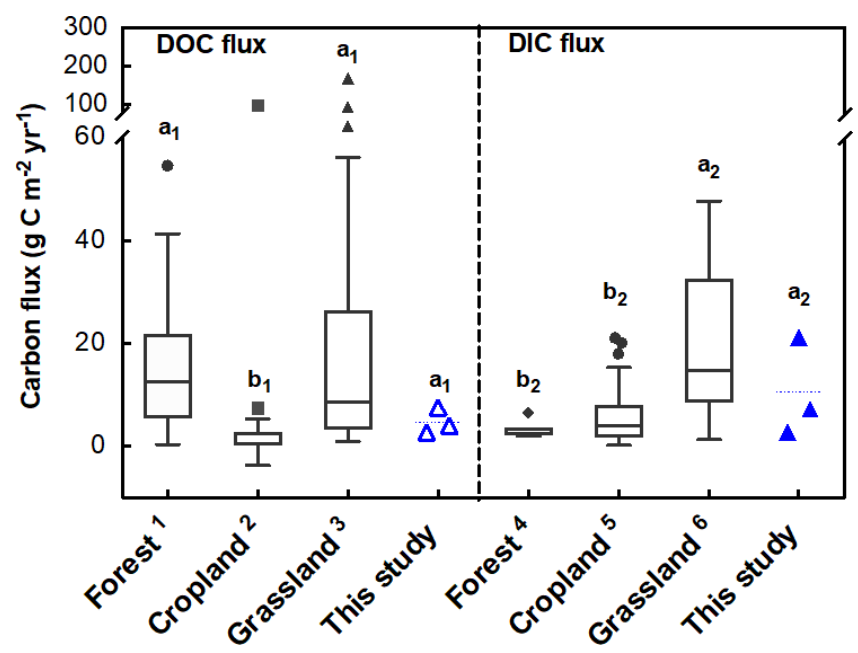

Figure 7. Leaching fluxes of dissolved organic carbon (DOC) and dissolved inorganic carbon (DIC) in this study compared with those reported in the literature. ${ }^{1} n=110$; data from Brooks et al. (1999), Fröberg et al. (2005, 2006, 2011), Gielen et al. (2011), Kindler et al. (2011), Lu et al. (2013), Michalzik et al. (2001), Sanderman et al. (2009). ${ }^{2} n=33$; data from Brye et al. (2001), Kindler et al. (2011), Siemens et al. (2012), Walmsley et al. (2011), Wang and Alva (1999), Gerke et al. (2016), Herbrich et al. (2017), Rieckh et al. (2014), Lenz (2014). ${ }^{3} n=46$; data from Brooks et al. (1999), Brye et al. (2001), Ghani et al. (2010), Kindler et al. (2011), McTiernan et al. (2001), Parfitt et al. (2009), Sanderman et al. (2009), Tipping et al. (1999). ${ }^{4} n=8$; data from Kindler et al. (2011). ${ }^{5} n=32$; data from Kindler et al. (2011), Siemens et al. (2012), Walmsley et al. (2011), Wang and Alva (1999), Gerke et al. (2016), Herbrich et al. (2017), Rieckh et al. (2014), Lenz (2014). ${ }^{6} n=9$; data from Brye et al. (2001), Kindler et al. (2011). Lowercase letters $\left(a_{1}, b_{1}\right.$ and $a_{2}, b_{2}$ ) represent significant difference levels of DOC and DIC fluxes, respectively, in different ecosystems determined by Duncan's multiple range test (one-way ANOVA, $p<0.05$ ). Dashed lines represent mean values for the investigated soils.

counted for $184 \%$ of NEP at XLHT, indicating the importance of biogenic DIC to leached inorganic carbon loss during EPEs. By comparison, NEP in the studied alpine grassland (68.5 $\mathrm{g} \mathrm{C} \mathrm{m}^{-2} \mathrm{yr}^{-1}$; Fu et al., 2009) is much higher than in typical temperate steppe. Hence, soil carbon loss through leaching and respired $\mathrm{CO}_{2}$ release accounted for $15 \%$ (DIC: $11 \%$, DOC: $4 \%$ ) and $7 \%$ of the NEP at GC, respectively. Nonetheless, the EPE-induced soil carbon loss relative to NEP was higher in this study than that estimated for grassland topsoil across Europe (12\% for DIC loss, $2 \%$ for DOC loss; Kindler et al., 2011) where the net ecosystem exchange (NEE) reported by Kindler et al. was used as NEP according to the report of Kirschbaum et al. (2001). This was partially attributed to the lower NEP and higher SIC content in XLHT and KQ soils, underscoring the fact that soil carbon leaching is more important in fragile ecosystems with low productivity.
The uncertainty related to the importance of leaching processes in the overall carbon budget along the "soil-riverocean" continuum is in the ultimate downstream fate of the leached carbon. If part of this carbon is retained in the surrounding soils or carried along from the river to the ocean in the form of DIC without outgassing into the air, it will not constitute a source of atmospheric $\mathrm{CO}_{2}$ on a relatively short term (over years or decades). However, soil columns used in our study have a depth $(60 \mathrm{~cm})$ typical of or even deeper than the average soil depth in the alpine grasslands of the Qinghai-Tibetan Plateau (Wang et al., 2001). Hence, we assume that the carbon leached in our experiments will have minimum retention in the soil. Furthermore, compared to DOC and DIC in the soil solution, the leached carbon is more likely to be subject to more intensified mineralization and outgassing during the land-ocean transfer given more intensified mixing processes, oxygen exposure, and photooxidation of terrestrial carbon upon releasing into the river (Hedges et al., 1997; Battin et al., 2009). Hence, we postulate that carbon leached from soils is more vulnerable to decomposition and/or release compared to that retained in the soil. That being said, it will be necessary to confirm our results and hypothesis using field-based leaching experiments to better understand the ultimate fate of leached soil carbon and whether it will be retained in the deeper soil or show higher degradability upon leaving the soil matrix. Such information will be complementary to our study and further elucidate the importance of leaching processes in terms of ecosystem carbon budget.

In summary, this study quantified and compared soil carbon loss through respired $\mathrm{CO}_{2}$ release and leaching in three typical grassland soils of northern China under simulated EPEs. Soil $\mathrm{CO}_{2}$ release was stimulated shortly after each $\mathrm{EPE}$, leading to an EPE-induced $\mathrm{CO}_{2}$ release equivalent to 32 and $72 \%$ of the NEP at XLHT and KQ (temperate grasslands) and $7 \%$ at GC (alpine grassland). By comparison, total soil carbon leaching fluxes accounted for 290, 120 and $15 \%$ of the NEP at XLHT, KQ, and GC, respectively, with DIC as the main form of carbon loss in the SIC-enriched XLHT and GC soils. In view of DIC sources, biogenic DIC loss derived from SOC mineralization contributed to more than half of the total leached DIC fluxes and accounted for $184 \%$ of the NEP at XLHT. Moreover, DIC loss increased with recurring EPEs in the XLHT soil with the highest $\mathrm{pH}$ due to the increased dissolution of soil carbonates and an elevated contribution of dissolved $\mathrm{CO}_{2}$ from $\mathrm{SOC}$ degradation. These results also imply that SOC mineralization in alkaline grassland soils during EPEs might be underestimated if measured only as $\mathrm{CO}_{2}$ emission from soil into the atmosphere. Admittedly, our results are based on artificial soil columns that destroyed natural soil structures, hence potentially increasing the contact between pore water and soil particles through changing soil porosity. Also, soil water content was set to $\sim 60 \%$ of maximum WHC initially in our experiment, which is higher than that in the field of temperate grasslands 
(XLHT and KQ). Thus, our measured DOC and DIC fluxes are likely to be higher than carbon leaching in the field due to greater water retention in drier soils. Hence, our estimate may represent an upper limit of soil carbon leaching potential under EPEs. Nonetheless, these results highlight the fact that leaching loss of soil carbon, especially in the form of DIC originated from biogenic and lithogenic carbonates, plays an important role in the regional carbon budget of grasslands located in arid and semiarid regions. Further research effort is needed to combine short-term laboratory experiments with long-term field measurements to fully assess the impacts of EPEs on the soil carbon budget in these areas. In addition, with a projected increase in EPEs under climate change, soil carbon leaching processes and the influencing factors warrant a better understanding and should be incorporated into soil carbon models when estimating carbon balance in grassland ecosystems.

Data availability. All data are available within this paper (Table 1) and in the Supplement (Dataset S1).

\section{The Supplement related to this article is available online at https://doi.org/10.5194/bg-15-1627-2018-supplement.}

Competing interests. The authors declare that they have no conflict of interest.

Acknowledgements. This study was financially supported by the Chinese National Key Development Program for Basic Research (2015CB954201, 2017YFC0503902), the National Natural Science Foundation of China (41422304, 31370491, 41603076), and the International Partnership Program of Chinese Academy of Sciences (grant no. 151111KYSB20160014). Xiaojuan Feng acknowledges start-up support from the National Thousand Young Talents recruiting plan of China. We thank two anonymous reviewers for their feedback on the paper. The data used are listed in the tables, figures, and Supplement of the paper.

Edited by: Kees Jan van Groenigen

Reviewed by: two anonymous referees

\section{References}

Ahmad, W., Singh, B., Dijkstra, F. A., and Dalal, R. C.: Inorganic and organic carbon dynamics in a limed acid soil are mediated by plants, Soil Biol. Biochem., 57, 549-555, 2013.

Artiola, J. F. and Walworth, J. L.: Irrigation water quality effects on soil carbon fractionation and organic carbon dissolution and leaching in a semiarid calcareous soil, Soil Sci., 174, 356-371, 2009.
Aslam, S., Iqbal, A., Deschamps, M., Recous, S., Garnier, P., and Benoit, P.: Effect of rainfall regimes and mulch decomposition on the dissipation and leaching of S-metolachlor and glyphosate: a soil column experiment, Pest Manag. Sci., 71, 278-291, 2015.

Bai, Y., Wu, J., Xing, Q., Pan, Q., Huang, J., Yang, D., and Han, $\mathrm{X}$.: Primary production and rain use efficiency across a precipitation gradient on the Mongolia plateau, Ecology, 89, 2140-2153, 2008.

Barré, P., Fernandez-Ugalde, O., Virto, I., Velde, B., and Chenu, C.: Impact of phyllosilicate mineralogy on organic carbon stabilization in soils: incomplete knowledge and exciting prospects, Geoderma, 235, 382-395, 2014.

Batjes, N. H.: Mitigation of atmospheric $\mathrm{CO}_{2}$ concentrations by increased carbon sequestration in the soil, Biol. Fertil. Soils, 27, 230-235, 1998.

Battin, T. J., Kaplan, L. A., Findlay, S., Hopkinson, C. S., Marti, E., Packman, A. I., Newbold, J. D., and Sabater, F.: Biophysical controls on organic carbon fluxes in fluvial networks, Nat. Geosci., 1, 95-100, 2008.

Battin, T. J., Luyssaert, S., Kaplan, L. A., Aufdenkampe, A. K., Richter, A., and Tranvik, L. J.: The boundless carbon cycle, Nat. Geosci., 2, 598-600, 2009.

Birch, H. F.: Mineralisation of plant nitrogen following alternate wet and dry conditions, Plant Soil, 20, 43-49, 1964.

Borken, W. and Matzner, E.: Reappraisal of drying and wetting effects on $\mathrm{C}$ and $\mathrm{N}$ mineralization and fluxes in soils, Glob. Change Biol., 15, 808-824, 2009.

Brooks, P. D., McKnight, D. M., and Bencala, K. E.: The relationship between soil heterotrophic activity, soil dissolved organic carbon(DOC) leachate, and catchment-scale DOC export in headwater catchments, Water Resour. Res., 35, 1895-1902, 1999.

Brye, K. R., Norman, J. M., Bundy, L. G., and Gower, S. T.: Nitrogen and carbon leaching in agroecosystems and their role in denitrification potential, J. Environ. Qual., 30, 58-70, 2001.

Burri, S., Niklaus, P., Buchmann, N., and Kahmen, A.: Response of grassland soil respiration to drought: Results from an ecosystem manipulation experiment including 19 sites differing in productivity and diversity, EGU General Assembly Conference Abstracts, 2015.

Cerling, T. E., Solomon, D. K., Quade, J., and Bowman, J. R.: On the isotopic composition of carbon in soil carbon dioxide, Geochim. Cosmochim. Ac., 55, 3403-3405, 1991.

Chen, H., Sun, J., Chen, X., and Zhou, W.: CGCM projections of heavy rainfall events in China, Int. J. Climatol., 32, 441-450, 2012.

Cole, J. J., Prairie, Y. T., Caraco, N. F., McDowell, W. H., Tranvik, L. J., Striegl, R. G., Duarte, C. M., Kortelainen, P., Downing, J. A., and Middelburg, J. J.: Plumbing the global carbon cycle: integrating inland waters into the terrestrial carbon budget, Ecosystems, 10, 172-185, 2007.

Davidson, E. A. and Janssens, I. A.: Temperature sensitivity of soil carbon decomposition and feedbacks to climate change, Nature, 440, 165-173, 2006.

Doctor, D. H., Kendall, C., Sebestyen, S. D., Shanley, J. B., Ohte, N., and Boyer, E. W.: Carbon isotope fractionation of dissolved inorganic carbon (DIC) due to outgassing of carbon dioxide from a headwater stream, Hydrol. Process., 22, 2410-2423, 2008. 
Donat, M. G., Lowry, A. L., Alexander, L. V., O’Gorman, P. A., and Maher, N.: Addendum: More extreme precipitation in the world's dry and wet regions, Nature Climate Change, 7, 154-158, 2017.

Edwards, C. T. and Saltzman, M. R.: Paired carbon isotopic analysis of Ordovician bulk carbonate $\left(\delta^{13} \mathrm{C}_{\text {carb }}\right)$ and organic matter $\left(\delta^{13} \mathrm{C}_{\text {org }}\right)$ spanning the Great Ordovician Biodiversification Event, Palaeogeogr. Paleocl., 458, 102-117, https://doi.org/10.1016/j.palaeo.2015.08.005, 2016.

Escolar, C., Maestre, F. T., and Rey, A.: Biocrusts modulate warming and rainfall exclusion effects on soil respiration in a semi-arid grassland, Soil Biol. Biochem., 80, 9-17, 2015.

Fröberg, M., Dan, B., Bo, B., Bryant, C., and Mulder, J.: Concentration and Fluxes of Dissolved Organic Carbon (DOC) in Three Norway Spruce Stands along a Climatic Gradient in Sweden, Biogeochemistry, 77, 1-23, 2006.

Fröberg, M., Kleja, D. B., Bergkvist, B., Tipping, E., and Mulder, J.: Dissolved organic carbon leaching from a coniferous forest floor - a field manipulation experiment, Biogeochemistry, 75, 271287, 2005

Fröberg, M., Hansson, K., Kleja, D. B., and Alavi, G.: Dissolved organic carbon and nitrogen leaching from Scots pine, Norway spruce and silver birch stands in southern Sweden, Forest Ecol. Manag., 262, 1742-1747, 2011.

Fu, G., Yu, J., Yu, X., Ouyang, R., Zhang, Y., Wang, P., Liu, W., and Min, L.: Temporal variation of extreme rainfall events in China, 1961-2009, J. Hydrol., 487, 48-59, 2013.

Fu, Y., Zheng, Z., Yu, G., Hu, Z., Sun, X., Shi, P., Wang, Y., and Zhao, X.: Environmental influences on carbon dioxide fluxes over three grassland ecosystems in China, Biogeosciences, 6, 2879-2893, https://doi.org/10.5194/bg-6-2879-2009, 2009.

Gerke, H. H., Rieckh, H., and Sommer, M.: Interactions between crop, water, and dissolved organic and inorganic carbon in a hummocky landscape with erosion-affected pedogenesis, Soil Till. Res., 156, 230-244, 2016.

Ghani, A., Müller, K., Dodd, M., and Mackay, A.: Dissolved organic matter leaching in some contrasting New Zealand pasture soils, Eur. J. Soil Sci., 61, 525-538, 2010.

Gielen, B., Neirynck, J., Luyssaert, S., and Janssens, I. A.: The importance of dissolved organic carbon fluxes for the carbon balance of a temperate Scots pine forest, Agr. Forest Meteorol., 151, 270-278, 2011.

Goswami, B. N., Venugopal, V., Sengupta, D., Madhusoodanan, M. S., and Xavier, P. K.: Increasing trend of extreme rain events over India in a warming environment, Science, 314, 1442-1445, 2006.

Gulley, J., Martin, J., and Moore, P.: Vadose $\mathrm{CO}_{2}$ gas drives dissolution at water tables in eogenetic karst aquifers more than mixing dissolution, Earth Surf. Process. Landf., 39, 1833-1846, 2014.

Harper, C. W., Blair, J. M., Fay, P. A., Knapp, A. K., and Carlisle, J. D.: Increased rainfall variability and reduced rainfall amount decreases soil $\mathrm{CO}_{2}$ flux in a grassland ecosystem, Glob. Change Biol., 11, 322-334, 2005.

Hartnett, H. E. and Devol, A. H.: Role of a strong oxygen-deficient zone in the preservation and degradation of organic matter: a carbon budget for the continental margins of northwest Mexico and Washington State, Geochim. Cosmochim. Ac., 67, 247-264, https://doi.org/10.1016/S0016-7037(02)01076-1, 2003.

Hedges, J. I., Keil, R. G., and Benner, R.: What happens to terrestrial organic matter in the ocean?, Org. Geochem., 27, 195-212, 1997.
Hendry, M. J., Mendoza, C. A., Kirkland, R., and Lawrence, J. R.: An assessment of a mesocosm approach to the study of microbial respiration in a sandy unsaturated zone, Ground Water, 39, 391400, 2001.

Hendy, C. H.: The isotopic geochemistry of speleothems - I, The calculation of the effects of different modes of formation on the isotopic composition of speleothems and their applicability as palaeoclimatic indicators, Geochim. Cosmochim. Ac., 35, 801824, 1971.

Herbrich, M., Gerke, H. H., Bens, O., and Sommer, M.: Water balance and leaching of dissolved organic and inorganic carbon of eroded Luvisols using high precision weighing lysimeters, Soil Til. Res., 165, 144-160, https://doi.org/10.1016/j.still.2016.08.003, 2017.

Hoover, D. L., Knapp, A. K., and Smith, M. D.: The immediate and prolonged effects of climate extremes on soil respiration in a mesic grassland, J. Geophys. Res.-Biogeo., 121, 1034-1044, 2016.

Howard, D. M. and Howard, P. J. A.: Relationships between $\mathrm{CO}_{2}$ evolution, moisture content and temperature for a range of soil types, Soil Biol. Biochem., 25, 1537-1537, 1993.

IUSS working group: World Reference Base for Soil Resources 2014, update 2015 International soil classification system for naming soils and creating legends for soil maps, World Soil Resources Reports, 2015.

Jessen, G. L., Lichtschlag, A., Ramette, A., Pantoja, S., Rossel, P. E., Schubert, C. J., Struck, U., and Boetius, A.: Hypoxia causes preservation of labile organic matter and changes seafloor microbial community composition (Black Sea), Sci. Adv., 3, e1601897, https://doi.org/10.1126/sciadv.1601897, 2017.

Jobbagy, E. G. and Jackson, R. B.: The vertical distribution of soil organic carbon and its relation to climate and vegetation, Ecol. Appl., 10, 423-436, https://doi.org/10.2307/2641104, 2000.

Kell, R. G., Montluçon, D. B., Prahlf, F. G., and Hedges, J. I.: Sorptive preservation of labile organic matter in marine, Nature, 37, 549-551, 1994.

Kirschbaum, M. U. F., Eamus, D., Gifford, R. M., Roxburgh, S. H., and Sands, P. J.: Definitions of some ecological terms commonly used in carbon accounting, Cooperative Research Centre for Carbon Accounting, Canberra, 2-5, 2001.

Kindler, R., Siemens, J. A. N., Kaiser, K., Walmsley, D. C., Bernhofer, C., Buchmann, N., Cellier, P., Eugster, W., Gleixner, G., and Grünwald, T.: Dissolved carbon leaching from soil is a crucial component of the net ecosystem carbon balance, Glob. Change Biol., 17, 1167-1185, 2011.

Knapp, A. K., Fay, P. A., Blair, J. M., Collins, S. L., Smith, M. D., Carlisle, J. D., Harper, C. W., Danner, B. T., Lett, M. S., and McCarron, J. K.: Rainfall variability, carbon cycling, and plant species diversity in a mesic grassland, Science, 298, 2202-2205, 2002.

Lal, R., and Kimble, J. M.: Pedogenic carbonates and the global carbon cycle, in: Global climate change and pedogenic carbonates, edited by: Lal, R., Kimble, J. M., Eswaran, H., and Stewart, B. S., CRC Press Inc, Bosa Roca, United States, 1-14, 2000.

Lal, R.: Carbon sequestration, Philos. T. R. Soc. B, 363, 815-830, 2008.

Lal, R.: Soil carbon sequestration impacts on global climate change and food security, Science, 304, 1623-1627, 2004. 
Lentz, R. D. and Lehrsch, G. A.: Manure and fertilizer effects on carbon balance and organic and inorganic carbon losses for an irrigated corn field, Soil Sci. Soc. Am. J., 78, 987-1002, 2014.

Li, Z. P., Han, F. X., Su, Y., Zhang, T. L., Sun, B., Monts, D. L., and Plodinec, M. J.: Assessment of soil organic and carbonate carbon storage in China, Geoderma, 138, 119-126, 2007.

Liu, B., Xu, M., Henderson, M., and Qi, Y.: Observed trends of precipitation amount, frequency, and intensity in China, 1960-2000, J. Geophys. Res.-Atmos., 110, D08103, https://doi.org/10.1029/2004JD004864, 2005.

Liu, B., Du, Y., Zhang, F., Lin, L., Li, Y.-k., Guo, X., Li, Q., and Cao, G.: Distribution of soil carbon in different grassland types of the Qinghai-Tibetan Plateau, J. Mt. Sci., 13, 1806-1817, 2016.

Liu, J., Fa, K., Zhang, Y., Wu, B., Qin, S., and Jia, X.: Abiotic $\mathrm{CO}_{2}$ uptake from the atmosphere by semiarid desert soil and its partitioning into soil phases, Geophys. Res. Lett., 42, 5779-5785, 2015.

Liu, S., Lu, X. X., Xia, X., Yang, X., and Ran, L.: Hydrological and geomorphological control on $\mathrm{CO}_{2}$ outgassing from low-gradient large rivers: An example of the Yangtze River system, J. Hydrol., 550, 26-41, https://doi.org/10.1016/j.jhydrol.2017.04.044, 2017.

Lu, X., Gilliam, F. S., Yu, G., Li, L., Mao, Q., Chen, H., and Mo, J.: Long-term nitrogen addition decreases carbon leaching in a nitrogen-rich forest ecosystem, Biogeosciences, 10, 3931-3941, https://doi.org/10.5194/bg-10-3931-2013, 2013.

Mayer, L. M.: Surface area control of organic carbon accumulation in continental shelf sediments, Geochim. Cosmochim. Ac., 58, 1271-1284, 1994.

McGrath, G. S., Hinz, C., and Sivapalan, M.: A preferential flow leaching index, Water Resour. Res., 45, W11405, https://doi.org/10.1029/2008wr007265, 2009.

McTiernan, K. B., Jarvis, S. C., Scholefield, D., and Hayes, M. H. B.: Dissolved organic carbon losses from grazed grasslands under different management regimes, Water Res., 35, 2565-2569, 2001.

Mi, N. A., Wang, S., Liu, J., Yu, G., Zhang, W., and Jobbagy, E.: Soil inorganic carbon storage pattern in China, Glob. Change Biol., 14, 2380-2387, 2008.

Michalzik, B., Kalbitz, K., Park, J. H., Solinger, S., and Matzner, E.: Fluxes and concentrations of dissolved organic carbon and nitrogen-a synthesis for temperate forests, Biogeochemistry, 52, 173-205, 2001.

Min, S.-K., Zhang, X., Zwiers, F. W., and Hegerl, G. C.: Human contribution to more-intense precipitation extremes, Nature, 470, 378-381, 2011.

Monger, H. C., Kraimer, R. A., Cole, D. R., Wang, X., and Wang, J.: Sequestration of inorganic carbon in soil and groundwater, Geology, 43, 375-378, 2015.

Morel, B., Durand, P., Jaffrezic, A., Gruau, G., and Molénat, J.: Sources of dissolved organic carbon during stormflow in a headwater agricultural catchment, Hydrol. Process., 23, 2888-2901, 2009.

Navarro-García, F., Casermeiro, M. Á., and Schimel, J. P.: When structure means conservation: Effect of aggregate structure in controlling microbial responses to rewetting events, Soil Biol. Biochem., 44, 1-8, 2012.

Nelson, P. N., Dictor, M. C., and Soulas, G.: Availability of organic carbon in soluble and particle-size fractions from a soil profile, Soil Biol. Biochem., 26, 1549-1555, 1994.
Parfitt, R. L., Percival, H. J., Dahlgren, R. A., and Hill, L. F.: Soil and solution chemistry under pasture and radiata pine in New Zealand, Plant Soil, 191, 279-290, 1997.

Parfitt, R. L., Mackay, A. D., Ross, D. J., and Budding, P. J.: Effects of soil fertility on leaching losses of N, P and C in hill country, N. Z. J. Agric. Res., 52, 69-80, 2009.

Parry, M., Canziani, O. F., Palutikof, J. P., van der Linden, P. J., and Hanson, C. E.: Climate change 2007: impacts, adaptation and vulnerability, Cambridge University Press Cambridge, 2007.

Parsons, A. N., Barrett, J. E., Wall, D. H., and Virginia, R. A.: Soil carbon dioxide flux in Antarctic dry valley ecosystems, Ecosystems, 7, 286-295, 2004.

Placella, S. A., Brodie, E. L., and Firestone, M. K.: Rainfall-induced carbon dioxide pulses result from sequential resuscitation of phylogenetically clustered microbial groups, P. Natl. Acad. Sci. USA, 109, 10931-10936, 2012.

Raich, J. W. and Schlesinger, W. H.: The global carbon dioxide flux in soil respiration and its relationship to vegetation and climate, Tellus B, 44, 81-99, 1992.

Raich, J. W. and Potter, C. S.: Global patterns of carbon dioxide emissions from soils, Global Biogeochem. Cy., 9, 23-36, 1995.

Ran, L., Lu, X. X., Richey, J. E., Sun, H., Han, J., Yu, R., Liao, S., and Yi, Q.: Long-term spatial and temporal variation of $\mathrm{CO}_{2}$ partial pressure in the Yellow River, China, Biogeosciences, 12, 921-932, https://doi.org/10.5194/bg-12-921-2015, 2015.

Reichstein, M., Bahn, M., Ciais, P., Frank, D., Mahecha, M. D., Seneviratne, S. I., Zscheischler, J., Beer, C., Buchmann, N., and Frank, D. C.: Climate extremes and the carbon cycle, Nature, 500, 287-295, 2013.

Ren, W., Tian, H., Tao, B., Yang, J., Pan, S., Cai, W. J., Lohrenz, S. E., He, R., and Hopkinson, C. S.: Large increase in dissolved inorganic carbon flux from the Mississippi River to Gulf of Mexico due to climatic and anthropogenic changes over the 21 st century, J. Geophys. Res.-Biogeo., 120, 724-736, 2015.

Rey, A., Petsikos, C., Jarvis, P. G., and Grace, J.: Effect of temperature and moisture on rates of carbon mineralization in a Mediterranean oak forest soil under controlled and field conditions, Eur. J. Soil Sci., 56, 589-599, 2005.

Rieckh, H., Gerke, H. H., Siemens, J., and Sommer, M.: Water and dissolved carbon fluxes in an eroding soil landscape depending on terrain position, Vadose Zone J., 13, 1-14, 2014.

Sanderman, J. and Amundson, R.: A comparative study of dissolved organic carbon transport and stabilization in California forest and grassland soils, Biogeochemistry, 92, 41-59, 2009.

Shi, Y., Baumann, F., Ma, Y., Song, C., Kühn, P., Scholten, T., and He, J. S.: Organic and inorganic carbon in the topsoil of the Mongolian and Tibetan grasslands: pattern, control and implications, Biogeosciences, 9, 2287-2299, https://doi.org/10.5194/bg9-2287-2012, 2012.

Siemens, J., Pacholski, A., Heiduk, K., Giesemann, A., Schulte, U., Dechow, R., Kaupenjohann, M., and Weigel, H. J.: Elevated air carbon dioxide concentrations increase dissolved carbon leaching from a cropland soil, Biogeochemistry, 108, 135148, https://doi.org/10.1007/s10533-011-9584-0, 2012.

Spencer, R. G. M., Aiken, G. R., Wickland, K. P., Striegl, R. G., and Hernes, P. J.: Seasonal and spatial variability in dissolved organic matter quantity and composition from the Yukon River basin, Alaska, Global Biogeochem. Cy., 22, GB4002, https://doi.org/10.1029/2008GB003231, 2008. 
Steffens, M., Kölbl, A., Totsche, K. U., and Kögel-Knabner, I.: Grazing effects on soil chemical and physical properties in a semiarid steppe of Inner Mongolia (PR China), Geoderma, 143, 63-72, 2008.

Sui, X. and Zhou, G.: Carbon dynamics of temperate grassland ecosystems in China from 1951 to 2007: an analysis with a process-based biogeochemistry model, Environ. Earth Sci., 68, 521-533, 2013.

Tan, W. F., Zhang, R., Cao, H., Huang, C. Q., Yang, Q. K., Wang, M. K., and Koopal, L. K.: Soil inorganic carbon stock under different soil types and land uses on the Loess Plateau region of China, Catena, 121, 22-30, 2014.

Tang, X., Wu, J., Xue, L., Zhang, M., Barthold, F., Breuer, L., and Frede, H.-G.: Major ion chemistry of surface water in the Xilin River Basin and the possible controls, Environ. Sci., 35, 131142, 2014.

Thaysen, E. M., Jacques, D., Jessen, S., Andersen, C. E., Laloy, E., Ambus, P., Postma, D., and Jakobsen, I.: Inorganic carbon fluxes across the vadose zone of planted and unplanted soil mesocosms, Biogeosciences, 11, 7179-7192, https://doi.org/10.5194/bg-117179-2014, 2014.

Tian, Q.-Y., Liu, N.-N., Bai, W.-M., Li, L.-H., and Zhang, W.-H.: Disruption of metal ion homeostasis in soils is associated with nitrogen deposition-induced species loss in an Inner Mongolia steppe, Biogeosciences, 12, 3499-3512, https://doi.org/10.5194/bg-12-3499-2015, 2015.

Tipping, E., Woof, C., Rigg, E., Harrison, A. F., Ineson, P., Taylor, K., Benham, D., Poskitt, J., Rowland, A. P., and Bol, R.: Climatic influences on the leaching of dissolved organic matter from upland UK moorland soils, investigated by a field manipulation experiment, Environ. Int. A, 25, 83-96, 1999.

Trumbore, S. E. and Czimczik, C. I.: An Uncertain Future for Soil Carbon, Science, 321, 1455-1456, 2008.

Unger, S., Máguas, C., Pereira, J. S., David, T. S., and Werner, C.: The influence of precipitation pulses on soil respirationAssessing the "Birch effect" by stable carbon isotopes, Soil Biol. Biochem., 42, 1800-1810, 2010.

Walmsley, D. C., Siemens, J., Kindler, R., Kirwan, L., Kaiser, K., Saunders, M., Kaupenjohann, M., and Osborne, B. A.: Dissolved carbon leaching from an Irish cropland soil is increased by reduced tillage and cover cropping, Agric. Ecosyst. Environ., 142, 393-402, 2011.
Wang, F., Yang, S., Higgins, W., Li, Q., and Zuo, Z.: Long-term changes in total and extreme precipitation over China and the United States and their links to oceanic-atmospheric features, Int. J. Climatol., 34, 286-302, 2014.

Wang, F. L. and Alva, A. K.: Transport of soluble organic and inorganic carbon in sandy soils under nitrogen fertilization, Can. J. Soil Sci., 79, 303-310, 1999.

Wang, H. J., Sun, J. Q., Chen, H. P., Zhu, Y. L., Zhang, Y., Jiang, D. B., Lang, X. M., Fan, K., Yu, E. T., and Yang, S.: Extreme climate in China: Facts, simulation and projection, Meteorol. Z., 21, 279-304, 2012.

Wang, S. Q., Zhu, S. L., and Zhou, C. H.: Characteristics of spatial variability of soil thickness in China, Geogr. Res., 20, 161-169, 2001.

Weiss, N., Blok, D., Elberling, B., Hugelius, G., Jørgensen, C. J., Siewert, M. B., and Kuhry, P.: Thermokarst dynamics and soil organic matter characteristics controlling initial carbon release from permafrost soils in the Siberian Yedoma region, Sediment. Geol., 340, 38-48, https://doi.org/10.1016/j.sedgeo.2015.12.004, 2016.

Yang, Y., Fang, J., Ji, C., Ma, W., Mohammat, A., Wang, S., Wang, S., Datta, A., Robinson, D., and Smith, P.: Widespread decreases in topsoil inorganic carbon stocks across China's grasslands during 1980s-2000s, Glob. Change Biol., 18, 3672-3680, 2012.

Yates, E. L., Detweiler, A. M., Iraci, L. T., Bebout, B. M., McKay, C. P., Schiro, K., Sheffner, E. J., Kelley, C. A., Tadić, J. M., and Loewenstein, M.: Assessing the role of alkaline soils on the carbon cycle at a playa site, Environ. Earth Sci., 70, 1047 1056, 2013.

Zhang, F., Jin, Z., Li, F., Yu, J., and Xiao, J.: Controls on seasonal variations of silicate weathering and $\mathrm{CO}_{2}$ consumption in two river catchments on the NE Tibetan Plateau, J. Asian Earth Sci., 62, 547-560, 2013.

Zhang, J., Quay, P. D., and Wilbur, D. O.: Carbon isotope fractionation during gas-water exchange and dissolution of $\mathrm{CO}_{2}$, Geochim. Cosmochim. Ac., 59, 107-114, https://doi.org/10.1016/0016-7037(95)91550-D, 1995. 